\title{
PALEOGEOGRAPHIC DISTRIBUTION OF THE SHASTASAURIDAE: GEOLOGICAL EVIDENCE FOR A WATERWAY CONNECTING THE ARCTIC SEA AND EASTERN TETHYS, DURING THE EARLY/MIDDLE ANISIAN
}

\author{
Anna Filosi $\odot \&$ Gabriele Bindellini $₫$ \\ Università degli Studi di Milano, Dipartimento di Scienze della Terra "A. Desio", via Mangiagalli 34, Milan, Italy. \\ gabriele.bindellini@unimi.it
}

\author{
KEYWORDS: \\ Anisian; \\ Shastasauridae; \\ waterway connection; \\ Tethys; \\ paleogeography.
}

\author{
Bullet-Points Abstract \\ - During Early/Middle Triassic Shastasauridae were located in western Tethys. \\ - We hypothesized three possible migration route for Early/Middle Triassic \\ shastasaurids. \\ - The Viking Graben could represent a waterway across norther Europe. \\ - This hypothesis is partially speculative, further evidence could come from \\ additional future data.
}

\section{INTRODUCTION}

Shastasauridae is a clade nested within the Ichthyosauria (Motani et al., 2017), and ranging from the late Olenekian to the Carnian, possibly also reaching the Rhaetian; it includes the first frankly pelagic ichthyosaurs, as well as Shonisaurus, one of the largest marine reptiles of all times. Due to its anatomical affinities, the genus Pessopteryx can be included in this group or at least be considered a stem taxon of it (McGowan \& Motani, 2003). Pessopteryx is dated back to the Late Olenekian and comes from the Vikinghøgda Formation, Spitsbergen, Svalbard. Besanosaurus (Dal Sasso \& Pinna, 1996) and Mikadocephalus are the only Shastasauridae known from the Anisian and they both come from the Besano Formation of Monte San Giorgio, western Tethys. Based on the known fossil record, during the Late Ladinian and Early Carnian, Shastasauridae become geographically restricted to China. From the late Carnian on, the group reaches a global distribution with reports from Central America, North America, China, Australia, and Tibet (e.g., Ji et al., 2016; Motani et al., 2017).

\section{Materials ANd Methods}

We tried to figure out which route the shastasaurids took to reach the Late Triassic global distribution. To do so, we consulted the available bibliography on the topic and we came up with three hypotheses: A) there was a "navigable" route that could connect the Arctic Sea and Eastern Tethys during the Early Anisian, crossing the central planes included between Greenland, Norway and England, and set across the Viking Graben (VG); B) the "migration" of this group took place through the circumnavigation of Pangea from the Svalbard area to reach the Western Tethys, passing by Siberia, China, Japan and Cimmerian blocks, or, on the other side, by the Americas, Antarctica, Australia, India and Africa; C) the intraPangea dextral shear, causing the transformation of Pangea B into Pangea A, could have led to the formation of some ephemeral transextensional basins, that could have favored the establishment of a waterway across North America and Europe.

The known fossil record of Shastasauridae does not support any of the three hypotheses because no shastasaurid remains have been found (or have not been yet published) along the three possible migration routes. On the other hand, hypothesis A may be supported by the studies of McKie (2017, p. 163), who suggests that "sea-level rise may have provided a mechanism by which marine waters gained access to many basins". In addition, hypothesis B and C take into account a much longer route, therefore, after evaluating Pangean paleogeography, we decided to give more attention to the shortest path. Given this, hypothesis A seems more likely than the others and so we investigate this possibility. Such hypothesis has never been clearly proposed and thus never received, in our opinion, the deserved attention.

Corresponding author's contact: anna.filosi@studenti.unimi.it

How to cite: Filosi \& Bindellini (2020). Paleogeographic distribution of the Shastasauridae: geological evidence for a waterway connecting the Arctic Sea and Eastern Tethys, during the early/middle Anisian. Fossilia, Volume 2020: 21-24. https://doi.org/10.32774/FosRepPal.2020.0606 


\section{Discussion}

During the latest Permian and Triassic, intracratonic rifts propagated into the arid continental central planes. These were infilled by sediment during seasonal monsoon flooding. Due to a generalized extensional dynamic, marine waters episodically accessed these subsea-level basins. As a result, marine waters inundated the area, locally originating evaporite basins. However, during the Triassic the mayor sedimentation originated from endorheic fluvial systems: the Northern Permian Basin (NPB) regions were mostly filled by sediments from large fluvial systems from Greenland, Fennoscandia, the Scottish Highlands, the remnant Variscan mountains, and more rarely from marine penetration of the Upper Muschelkalk.

Following McKie (2017), during the Early and Middle Anisian, in the NPB and the VG basins, three major types of facies (Fig. 1) have been described: 1) fluvial sandstone, 2) playa mudstone and sabkha, 3) halite.

1) Fluvial sandstones were common in these basins. Distal fringes, extending basinwards, were common, comprising mud-rich successions degrading into subaerial and subaqueous playa facies. Other facies like reworked aeolian sediment are also present and associated to arid episodes. However, there is no evidence of deep and large rivers. On the contrary, the land was dominated by relatively shallow streams, up to $5 \mathrm{~m}$ depth, characterized by multiple flow directions. Paleocurrent data indicate broadly axial flow, dominated by current directed southward, towards the Southern North Sea, with an alternating dominance of axial and transverse flow (Fig. 1).

2) Playa mudstones are typically red-colored, siltprone heterolithic deposits, and are characterized by the presence of nodular anhydrite or gypsum within the succession in coincidence of coastal sabkha. The depositional setting of the playa mudstone may be the consequence of episodes of desiccation of marine influenced basins. Marsh conditions are also testified by the paleobotanical fossil record. A current analogous of these playa mudstones is the Rann of Kutch (McKie \& Williams, 2009), which is a flat desert of salty clay and mudflats, 15 meters above sea level. During the summer monsoon in India, it fills with marine water. In very wet years, the Gulf of Kutch becomes connected to the Gulf of Cambay on the East, through an ephemeral water channel, which is more than 400 $\mathrm{km}$ long.

3) Halite bodies are large and quite common. These are included within playa facies. McKie (2017) hypothesized that the area covered by halite is now considerably more restricted than the original brine body.

What could have led a hypothetical shastasaurid taxon to cross the VG and the SPB, until reaching the Muschelkalk, implies the presence of an environmental pressure exerted by a competitor that may be represented by a sympatric Cymbospondylidae. This could have forced the shastasaurid taxon to explore new areas and then led it to cross the continent through a possible "navigable route" that opened several times, reaching the Muschelkalk basin and then the Tethys.

\section{Conclusions}

Given the evidence for:

- the playa mudstone occasionally flooded by marine waters during the early-middle Anisian;

- the presence of a manly southward river stream through the Viking Graben;

- a humid phase during the middle Anisian, named the Bythinian-humid pulse (e.g., Stefani et al., 2010);

we cannot exclude the establishment of a "navigable" route for shastasaurids, as proposed in hypothesis A. The study is currently undergoing. Further evidence could come from:

- new findings from the mentioned localities, in particular from China and Svalbard.

- supplemental core sampling from the VG and an aimed facies study.

- additional studies focused on the paleogeography of other taxa that may have followed a similar dispersal pattern (e.g. Mixosauridae, Cymbospondilidae, Omphalosaurus).

\section{REFERENCES}

Dal Sasso C. \& Pinna G. (1996). Besanosaurus leptorhynchus n. gen. n. sp., a new shastasaurid ichthyosaur from the Middle Triassic of Besano (Lombardy, N.Italy). Paleontologia Lombarda, 4: 3-23.

Ji C., Jiang D. Y., Motani R., Rieppel O., Hao W. C. \& Sun Z. Y. (2016). Phylogeny of the Ichthyopterygia incorporating recent discoveries from South China. Journal of Vertebrate Paleontology, 36 (1): e1025956.

McGowan C. \& Motani R. (2003). Handbook of Paleoherpetology, Part 8 Ichthyopterygia. Verlag Dr. Friedrich Pfeil, Munich: 1-175.

McKie T. (2017). Paleogeographic evolution of latest Permian and Triassic salt basins in Northwest Europe. In Soto J. I., Flinch J., \& Tari G. (eds.), Permo-Triassic Salt Provinces of Europe, North Africa and the Atlantic Margins, Elsevier: 159-173.

McKie T. \& Williams B. (2009). Triassic palaeogeography and fluvial dispersal across the northwest European Basins. Geological Journal, 44 (6): 711-741. 


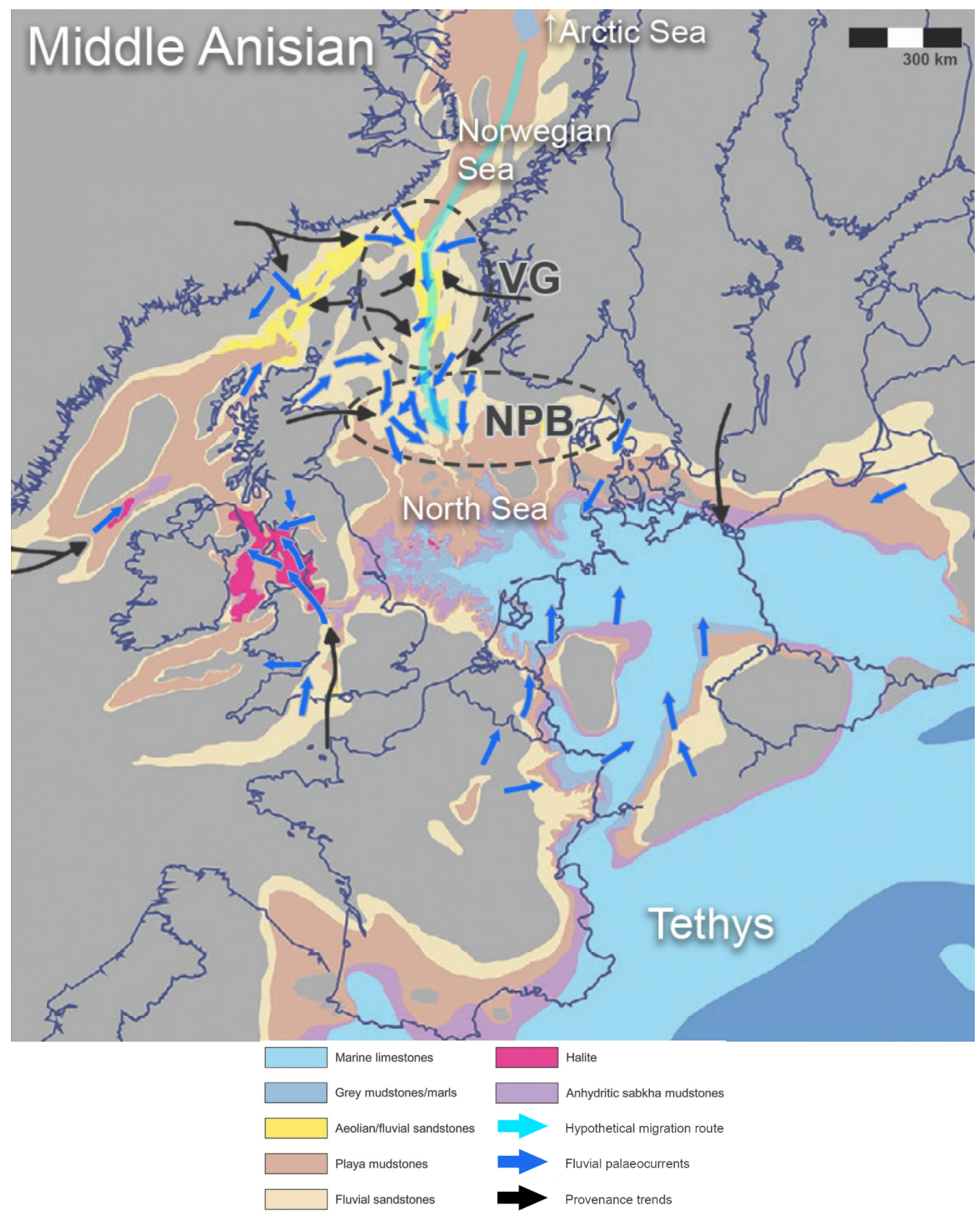

Fig. 1. Middle Anisian facies distribution in north-western Europe. VG = Viking Graben; NPB = Northern Permian Basin. Modified from McKie (2017) and McKie \& Williams (2009). 
Motani R., Jiang D. Y., Tintori A., Ji C. \& Huang J. D. (2017). Pre-versus post-mass extinction divergence of Mesozoic marine reptiles dictated by time-scale dependence of evolutionary rates. Proceedings of the Royal Society B: Biological Sciences, 284 (1854): 20170241.
Stefani M., Furin S. \& Gianolla P. (2010). The changing climate framework and depositional dynamics of Triassic carbonate platforms from the Dolomites. Palaeogeography, Palaeoclimatology, Palaeoecology, 290 (1-4): 43-57. 